\title{
Resulting Trusts in Canada
}

\section{ROBERT CHAMBERS ${ }^{*}$}

This article looks at the resulting trust and its creation as a response to an event, that of unjust enrichment. The author looks at how and why the resulting trust arises; the role of key presumptions in determining whether or not a resulting trust is present; the role of intention in creating a resulting trust; and how all resulting trusts serve to effect restitution of unjust enrichment. The author argues that Canadian courts have focused on the constructive trust and its relationship with unjust enrichment, to the detriment of achieving understanding in this area. This has left the resulting trust on the sidelines, when it could more appropriately be used to create greater certainty and prediclability.
Cet article examine la fiducie par déduction et sa création suite à un événement, soit l'enrichissement sans cause. L'auteur étudie le comment et le pourquoi de la fiducie par déduction, le rôle des grandes présomptions dans l'établissement de l'existence ou de l'absence d'une fiducie par déduction, le rôle de l'intention dans la création d'une fiducie par déduction et comment toutes les fiducies par déduction servent à la restitution de l'enrichissement sans cause. L'auteur prétend que les tribunaux canadiens ont ciblé la fiducie judiciaire et ses liens avec l'enrichissement sans cause au détriment de la compréhension du domaine. C'est ainsi que la fiducie par déduction a été écartée alors qu'elle conviendrait mieux à la création d'une plus grande certitude et prévisibilité.

\section{TABLE OF CONTENTS}

I. INTRODUCTION . . . . . . . . . . . . . . . . . 379

II. THE CREATION of Resulting TrustS $\ldots \ldots \ldots \ldots \ldots \ldots \ldots 379$

A. What is A TRUST? . . . . . . . . . . . . . 379

B. Classification of Trusts $\ldots \ldots \ldots \ldots \ldots \ldots \ldots \ldots 380$

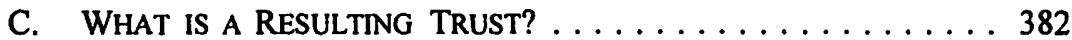

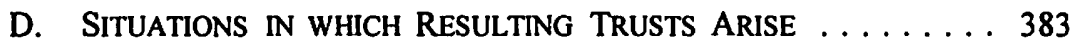

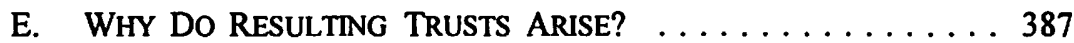

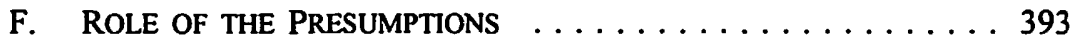

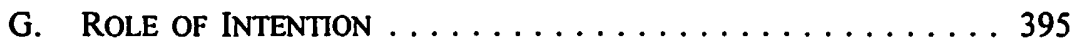

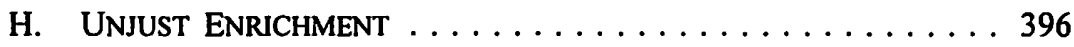

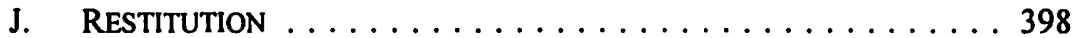

III. RESPONSES TO UNJUST ENRICHMENT $\ldots \ldots \ldots \ldots \ldots \ldots \ldots . \ldots 99$

A. TRUSTS OF UnJust ENRICHMENT $\ldots \ldots \ldots \ldots \ldots \ldots .400$

B. PROPERTY RIGHTS CREATED BY

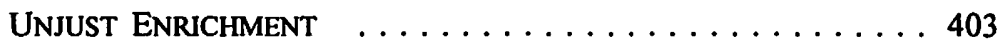

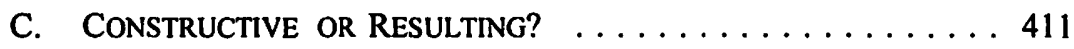

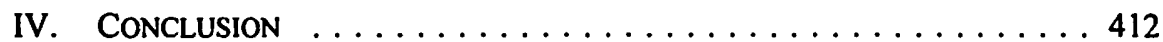

Associate Professor, University of Alberta Faculty of Law. This article was presented at the 29th annual Workshop on Commercial and Consumer Law at McGill University on 15 October 1999. The author would like to thank Professor David Stevens and the other organizers of the workshop (for their kind invitation to present this article), the commentators and participants at the workshop (for their helpful comments on this article), Dr. Mitchell Mclnnes (for suggesting this topic and encouraging the author to present it at the workshop), and Professor Peter Birks (who inspired and supervised much of the research and writing which is the source of this article). 


\section{INTRODUCTION}

This article is divided into two main parts. The purpose of the first, entitled "The Creation of Resulting Trusts," is to show that all resulting trusts reverse unjust enrichment. The second, entitled "Responses to Unjust Enrichment," is more controversial in Canada. It is intended to show that it is not the constructive trust, but the resulting trust which is equity's way of creating property rights to effect restitution of unjust enrichment (along with equitable liens, rescission, and rectification). This continues the work of my recent book, Resulting Trusts.' Although that book is primarily about the resulting trust in English law, it draws on jurisprudence from Australia, Canada, New Zealand, and the United States. There are no features of Canadian law (outside Quebec) which negate its central arguments.

The possibility that resulting trusts respond to unjust enrichment is obscured in Canada by a series of well known cases concerning the division of family property on the breakdown of a marriage or similar relationship. In Pettkus v. Becker, Dickson J. stated that "[t]he principle of unjust enrichment lies at the heart of the constructive trust." 2 This left the resulting trust languishing on the sidelines for the past twenty years while the attentions of judges and lawyers were focused on the constructive trust and its relationship to unjust enrichment. However, the family property cases say little about the resulting trust and nothing about its relationship to unjust enrichment. Nor do they provide guidance for the creation of trusts in response to unjust enrichment in situations other than the breakdown of a family.

\section{The Creation of Resulting Trusts}

\section{A. What is a Trust?}

A trust exists when a person (called a trustee) is required by a court of equity to use some right for the benefit of another person or for a specific (usually charitable) purpose. The right held in trust (called the subject of the trust) may be any sort of right, whether personal or property and whether legal or equitable. A person entitled to the benefit of a trust is called a beneficiary of the trust and, in most cases, has an equitable property right to the subject of the trust.

Trusts operate parasitically. In contrast to legal property rights, which relate directly to things such as land or goods, equitable property rights relate to other rights. For example, the thing subject to a legal fee simple estate is a space on the earth. If that estate is held in trust, the beneficiary of the trust has an equitable fee simple estate. However, the thing subject to that equitable property right is not the space itself, but the trustee's legal right to that space. 


\section{B. Classification of Trusts}

Trusts are usually classified according to the manner in which they are created. There are three main categories: express, resulting, and constructive. There is a fourth category of implied trusts. However, it has fallen into disuse for reasons discussed briefly below. Regardless of the number of nominate categories, it is necessary to have a category of miscellaneous "other" trusts, which do not belong elsewhere. For example, there are many trusts created by statute which cannot be labelled as express, resulting, constructive, or implied. These may now be sufficient in number to warrant the creation of a new category of statutory trusts, but that would not obviate the need to maintain some place for the remaining miscellany.

\section{EXPRESS TRUSTS}

An express trust is created by the intention to create it. A person with a right (called a settlor) can "settle" the subject matter of the trust by intending to create that trust and by taking the appropriate steps to give effect to that intention. Like other property rights, the formalities required depend on the nature of the right and the nature of the thing subject to that right. Where a right to land is to be held in trust, the intention to create that trust must be manifest in writing and signed by the settlor. Testamentary express trusts must be created in a manner which complies with the formalities required for the creation of wills. Other rights can be settled in trust informally. The settlor can become the trustee, by declaring that he or she holds a right in trust for another person, or can become the beneficiary, by transferring a right to another person to hold in trust for the settlor.

\section{CONSTRUCTIVE TRUSTS}

Constructive trusts arise by operation of law (other than statute). In other words, they arise in response to events other than the properly expressed intention to create them. Admittedly, this definition does nothing more than exclude express trusts from the category of constructive trusts. There is considerable controversy over the identification of the events which give rise to constructive trusts. In Soulos v. Korkontzilas, ${ }^{3}$ the majority of the Supreme Court of Canada said that there were two main categories of events which create constructive trusts. McLachlin J. stated:

The first category concerns property obtained by a wrongful act of the defendant, notably breach of fiduciary obligation... The second category concerns situations where the defendant has not acted wrongfully in obtaining the property, but where he would be unjustly enriched to the plaintiff's detriment by being permitted to keep the property for himself. ${ }^{4}$

In "Constructive Trusts in Canada," I argued that these categories are either incomplete or incorrect. There are many constructive trusts that cannot be explained as

[1997] 2 S.C.R. 217, 146 D.L.R. (4th) 214 [hereinafter cited to D.L.R.].

lbid. at 227.

(1999) 37 Alta. L. Rev. 173. 
responses either to wrongdoing or to unjust enrichment. For example, a constructive trust can arise on the making of a specifically enforceable contract of sale or to give effect to a secret trust, mutual wills, or an incomplete gift. Dr. Gbolahan Elias called these trusts "perfectionary," in Explaining Constructive Trusts, ${ }^{6}$ by which he meant that they are created by operation of law to perfect otherwise ineffective intentions to benefit others. Equity's intervention in most of these situations is justified on the basis that the beneficiary of the constructive trust has detrimentally relied on, or given valuable consideration for, the fulfilment of that intention.

Perfectionary constructive trusts clearly belong outside McLachlin J.'s two categories. This means either that at least one more category must be added or that at least one of her two categories is incorrect. There is nothing wrong with the first category. The acquisition of property through the commission of a wrong has long been accepted as an event which gives rise to a constructive trust. ${ }^{7}$ However, there are doubts about the second category, unjust enrichment.

There are several judgments of the Supreme Court of Canada which say that constructive trusts arise in response to unjust enrichment. However, on closer inspection, these are not what they seem. For example, in Lac Minerals v. International Corona Resources, ${ }^{8}$ the plaintiff obtained restitution of a gold mine acquired by the defendant in breach of confidence, fiduciary duty, or both. Although it was discussed in terms of unjust enrichment, it is really a case of restitution of property acquired through the commission of a wrong.'

The primary authority for the Canadian view that constructive trusts respond to unjust enrichment is a series of family property cases. As discussed in "Constructive Trusts in Canada" and below in the section on "Responses to Unjust Enrichment," these cases cannot be explained as restitution of unjust enrichment. Although unjust enrichment is present, the constructive trust of the family home is not a direct response to that enrichment. It arises in response to some other event, namely the expectation of acquiring an interest in the family home during the course of the marriage or similar relationship. Therefore, these trusts are better regarded as perfectionary.

\section{IMPLIED TRUSTS}

The implied trust continues to be listed as a category of trusts, possibly because it is found in the Statute of Frauds, $1677^{10}$ and a number of its offspring, concerning the formalities required for the creation of trusts of land. For example, Ontario's Statute of

6 (Oxford: Clarendon Press, 1990).

7 See Keech v. Sandford (1726), Sel. Cas. t King 61, 25 E.R. 223; Pre-Cam Exploration \& Development v. McTavish, [1966] S.C.R. 55I, 57 D.L.R. (2d) 557.

[1989] 2 S.C.R. 574, 61 D.L.R. (4th) 14.

See L.D. Smith, "The Province of the Law of Restitution" (1992) 71 Can. Bar Rev. 672 at 687-688; M. McInnes, "The Canadian Principle of Unjust Enrichment" (1999) 37 Alta. L. Rev. 1 at 28-31. 
Frauds refers to a trust which "arises or results by implication or construction of law." It is also found in other statutes, such as Alberta's Land Titles Act, which prohibits the registrar from making a notation on a certificate of title of any trust, "whether express, implied or constructive." 12

There is a great deal of uncertainty about what is meant by "implied trust." For some, it means a trust created by an intention which has not been clearly expressed, but is proved to exist from the circumstances. For some, it means a trust implied by law and, for others, it is a synonym for a resulting trust. On any view, there is no need to maintain implied trusts as a separate category, since the trusts which might fall within its borders can all be classified safely as express, constructive, or resulting. The implied trust has been left on the shelf because of its ambiguity and lack of utility. However, no one is willing to throw it away just yet because it is still listed in the statute books.

\section{What is a Resulting Trust?}

Unlike implied trusts, resulting trusts continue to have an important role in the modern law of trusts. However, even if we ignore implied trusts and the controversy surrounding the events which give rise to constructive trusts, a proper classification of trusts remains difficult because of uncertainty surrounding the resulting trust. What is a resulting trust and what separates it from an express or constructive trust?

There are two main problems arising from our system of classification. First, the labels "express" and "constructive" seem to describe two exhaustive categories of trusts: those created by an intention to create a trust and those created by events other than intention. These definitions leave no room for a third category of resulting trusts. One or both of these must be modified to exclude resulting trusts. As discussed below, I believe it is the constructive trust which must make room for the resulting trust as another trust created by operation of law.

The second problem is created by the label "resulting." Unlike the terms "express" and "constructive," it is directed not at the creation of the trust but at its effect. The term "resulting" (from the Latin, resalire) means "to jump back." In every case of resulting trust, someone has received an asset at the expense of another person and the trust causes the beneficial ownership of that asset to be returned to that other person. As Morrison J. said in Baird v. Columbia Trust Co., "the person in whose favour the trust arises is the person who provided the property or equitable interest vested in the person bound by the trust."13

In "Equity, Conscience, and Unjust Enrichment," Professor Peter Birks said that the organization of trusts as express, constructive, or resulting is a "bent classification":

R.S.O. 1990, c. S-19, s. 10.

R.S.A. 1980 , c. L-5, s. 51.

(1915), 22 D.L.R. 150 at 151 (B.C.S.C). 
[W] hen we say that trusts are express, implied, resulting, or constructive, the word 'resulting' is on its face the odd man out, for 'resulting' indicates that the beneficial interest resalit (jumps back), and the other terms are focused on the mode of creation, not the location of the beneficial interest. ${ }^{14}$

As Birks also pointed out, in An Introduction to the Law of Restitution, ${ }^{15}$ trusts can be "resulting in pattern" regardless of the manner in which they are created. For example, if I transfer my car to you with the instruction that you are to hold it in trust for me, I have created an express trust which is resulting in pattern. There are also statutory trusts which are resulting in pattern. For example, Alberta's Residential Tenancies Act says of security deposits that "[t]he landlord is the trustee of the money in the trust account on behalf of the tenant who paid it."16

The category of resulting trusts is not intended to cut across the other categories of trusts and remove those express, constructive, and statutory trusts which happen to be resulting in pattern. It is supposed to align with the others as a category based on the events which create them. Unfortunately, there is no consensus among lawyers and judges regarding the identity of those events. Despite this uncertainty, those who are familiar with this area of law have little difficulty recognizing the resulting trusts which they encounter. Those trusts result in pattern and arise in certain well-known situations. In other words, we know a resulting trust when we see it, but might have difficulty explaining why it is neither express nor constructive.

\section{Situations in Which Resulting Trusts ARise}

There are two main situations in which resulting trusts are known to arise: first, when someone receives an apparent gift and, second, when an express trust fails to dispose of all of the assets held in trust. It is uncontroversial that a trust which arises in one of these situations is properly classified as resulting if it is resulting in pattern. These two categories are not exhaustive of the situations in which resulting trusts arise. For example, the "Quistclose trust"17 is, or at least can be, resulting. ${ }^{18}$ However, when stepping outside the two traditional categories of resulting trusts, the path becomes much less certain.

\section{APPARENT GiFTS}

Equity tends to be suspicious of gifts and often asks the recipient of an apparent gift to prove that it was intended as a gift. The failure to do so means that it will be held in trust for the apparent donor. In other words, the apparent gift creates a presumption of resulting trust. As Spence J. said, in Goodfriend v. Goodfriend, it is "trite law ... that where a person transfers his property into another's name gratuitously a resulting trust

14 (1999), 23 M.U.L.R. 1 at 10.

is Rev. ed., (Oxford: Clarendon Press, 1989) at 62.

$16 \quad$ R.S.A. 1980, c. R-15.3, s. 37.1(2).

$17 \quad$ Named after Barclays Bank v. Quistclose Investments (1968), [1970] A.C. 567 (U.K.H.L.).

18 See Re EVTR, [1987] B.C.L.C. 646 (C.A.). 
in favour of the grantor is created and the transferee must prove, in order to retain title, that a gift was intended by the transferor." 19

In some cases, the relationship of the parties is such that an apparent gift does not raise any suspicions. The apparent gift is assumed to be intended as such. A resulting trust will not arise in that case unless it is proven that the apparent donor did not intend to make a gift. This is called the presumption of advancement because, at one time, fathers were expected to make gifts to their children to advance them in life. Therefore, when a father made an apparent gift to his child, it was assumed to be intended as a gift unless the contrary was shown.

Today, a presumption of advancement applies to apparent gifts to children from their parents, guardians, or persons standing in loco parentis to them (who are all referred to below as parents). Unless modified by statute, it also applies to apparent gifts from husbands to their wives. In other situations, the presumption of resulting trust applies. ${ }^{20}$ Strangely, the presumption of advancement does not apply to apparent gifts from adult children to their parents, from wives to their husbands, between siblings, or between other close relatives or friends. The presumption of advancement is not triggered by the nature of a particular relationship. The presence of love, affection, or other factors which might indicate that an apparent donor intended to give is not relevant to the choice of presumption. If the apparent donor is the parent or (perhaps) husband of the apparent donee, the transaction is assumed to be a gift. In other cases, it is assumed not to be.

In many provinces and territories, the presumption of advancement between husbands and wives has been modified by statute. For example, New Brunswick's Marital Property Act states:

The rule of law applying a presumption of advancement in questions of the ownership of property as between husband and wife is abolished and in place thereof the rule of law applying a presumption of a resulting trust shall be applied in the same manner as if they were not married.... ${ }^{21}$

This section does not apply to jointly owned assets, which are deemed to be owned beneficially by the spouses jointly. Therefore, at least in the context of the breakdown of the marriage, the presumption of advancement no longer applies where a husband makes an apparent gift to his wife of the sole ownership of an asset or an interest in it as a tenant in common. Conversely, the presumption of resulting trust no longer applies to an apparent gift from a wife to a husband of a joint interest in an asset.

The rules concerning the presumption of advancement may seem strange to the modern eye. They are oddly artificial and somewhat removed from the facts which would provide an answer to the question they are designed to answer: did an apparent donor really intend to make a gift? Perhaps stranger still is the existence of the

19 [1972] S.C.R. 640, 22 D.L.R. (3d) 699 at 702.

$20 \quad$ See, e.g., Re Dagle (1990), 70 D.L.R. (4th) 201 (P.E.I.S.C.).

$21 \quad$ S.N.B. 1980 , c. M-1.1, s. 15 
presumption of resulting trust. Why does equity intervene at all when an apparent gift is made? Why not assume that people intend the natural consequences of their actions? The answer to these questions requires a brief discussion of the forerunner of the resulting trust: the resulting use.

Prior to the Statute of Uses, $1535,{ }^{22}$ a great deal of the land in England was held to the use of another. The use was a device similar to the modern trust, by which the legal owner of an estate could be compelled to use that estate for the benefit of another. It was often used to circumvent two problems which arose when the owner died: feudal incidents and the inability to devise real property by will. On the death of the owner, the estate would pass to her or his heir, but not without considerable expense in the form of feudal incidents due to the lord from whom the owner held tenure. The lord would be entitled to a year's rent for recognizing the heir's right to inherit and would also be entitled to the benefits of wardship if the heir was a minor. ${ }^{23}$

The use allowed the owner to avoid these problems. The land could be transferred to several people (called feoffees que use) to hold the land jointly to the former owner's use. Feoffees who died could be replaced so that the land never descended to an heir and feudal incidents were never paid. The former owner could choose the persons entitled to the use of the land on her or his death. This was, in substance, the power to devise land by will.

The popularity of the use had at least two important consequences: the Statute of Uses and the resulting use. First, the avoidance of feudal incidents caused such a significant loss of revenue to the Crown (then Henry VIII) that the Statute of Uses, 1535 was enacted. It eliminated uses of most freehold land by "executing the use." This removed the legal estate from the feoffees que use and transferred it to the beneficiary of that use.

The second consequence (the creation of the resulting use) occurred in the 15th century. It had become so common for owners to transfer land to be held for their own use, that the court began to presume that a transfer made for no consideration was intended to be for the transferor's own use. It is important to note that the concept of consideration had not then acquired its technical meaning in the modern law of contract. As Birks said, “A 'consideration' was once no more than a 'matter considered', and the consideration for doing something was the matter considered in forming the decision to do it."24 The consideration (or reason) for a transfer of land was apparent when it was sold for value. It was also apparent when the land was given by a father to his child. ${ }^{25}$ The presumption of resulting use evolved into the presumption of resulting trust after the modern trust arose from the ashes of the executed use.

22 (U.K.), 27 Hen. VIII, c. 10.

23 See A.W.B. Simpson, A History of the Land Law, 2d ed. (Oxford: Clarendon Press, 1986) at 15-20.

$24 \quad$ Supra note 15 at 223.

$25 \quad$ See Grey v. Grey (1677), 2 Swans. 594 at 597, 36 E.R. 742. 
Although the presumptions seem somewhat out of step with the times, it must be remembered that the presumption of resulting trust applies to all apparent gifts, except where the donor is the donee's parent or (perhaps) husband. In other words, the presumption of resulting trust is the general rule and the presumption of advancement is a limited exception to that rule. The presumption of resulting trust can be justified today as a safeguard against the unintended loss of assets. There are many reasons why one person might transfer legal title to another person or purchase an asset in another person's name. The presumption of resulting trust is equity's way of confirming that an apparent gift really was intended as such.

The presumption of advancement might be explained as a limited exception in situations where the protection of the presumption of resulting trust is not required. Economically more powerful parents and husbands did not need to be protected from unintentional transfers of wealth to their children and wives. However, if this is the rationale behind the modern presumption of advancement, then two adjustments may be needed. First, as the balance of power within the institution of marriage is achieved, husbands should become entitled to the same protection of the presumption of resulting trust which everyone enjoys (except parents). This has already been partially accomplished by statute. Second, there is no need to apply the presumption of advancement to apparent gifts from parents to adult children who have achieved economic independence. Particularly in cases where elderly parents are dependent on their adult children, a large gift from a parent to a child might well be a situation of which equity ought to be suspicious.

\section{TRUSTS WhICH FAIL}

The second traditional situation in which resulting trusts arise is the failure of an express trust. If assets are transferred to trustees to be held in trust, and that trust fails to dispose of all those assets for any reason, the trustees will (in most cases) hold the remainder on resulting trust for the settlor (or her or his estate if the settlor is deceased).

The reasons why express trusts fail are not really relevant to this discussion. It may be due to a failure to specify the beneficiaries or purposes (called the objects) of the trust. For example, a transfer of assets to someone "in trust," without more, will normally produce a resulting trust for the settlor. ${ }^{26}$ The settlor may have chosen trust objects which are invalid and unenforceable, failed to comply with the formalities required for creating an express trust of land or a testamentary trust, or simply failed to allocate the entire subject matter of the trust among the chosen trust objects. The failure of the express trust and the possibility of a resulting trust for the settlor are separate issues.

In every case where assets are transferred to trustees to be held in trust and that trust fails to dispose of those assets, there is a further question to be answered: are the 
trustees entitled to retain what is left for their own benefit or must they hold it on resulting trust for the settlor? Normally, the question is easy to answer. The settlor's instruction to hold the assets in trust is a strong indication that he or she did not intend to make a gift of the surplus to the trustees. However, there are many cases in which the trustees were entitled to keep the remaining trust assets because the evidence revealed that the settlor did intend to benefit them.

For example, in Moffit v. Moffit, ${ }^{27}$ a mother transferred land to her son in trust for herself and her husband for their joint lives. The trust deed did not provide for the use or distribution of the land after the death of the mother and her husband. After the mother died, the court was asked to decide whether there was a resulting trust of the land for her estate or whether the son was entitled to retain it for his own benefit. Wilson J. carefully examined the details surrounding the whole transaction, which involved lands belonging to the son as well as the land settled in trust by the mother, and concluded "that the settlor intended to benefit the trustee... Hence I say there is no resulting trust." 28

The assumption that trustees are not intended to retain surplus trust assets for their own benefit is not normally referred to as the presumption of resulting trust. However, the two situations are very similar. Trustees do not normally provide consideration for the transfer of property in trust and, therefore, if they are allowed to retain the surplus, there is an apparent gift. The settlor's instruction to hold the assets in trust is strong evidence that a gift was not intended. However, it is possible for the trustees to rebut that assumption with admissible evidence showing that a gift of the surplus was intended.

\section{E. Why Do Resulting Trusts ARISe?}

So, why do resulting trusts arise? The argument presented here is that all resulting trusts arise in response to the same type of event: the receipt of an asset by someone who was not intended to be its beneficial owner. In other words, there was a lack of intention to make a gift. The resulting trust arises by operation of law to return the beneficial ownership of that asset to the person at whose expense it was obtained. That person might be the previous owner who transferred the asset to the resulting trustee or the person who paid all or part of the purchase price for the transfer.

This explanation of the resulting trust is somewhat controversial because of two contrary theories. The first is that resulting trusts respond not to one, but to two different events. According to this theory, there are two kinds of resulting trusts: "presumed resulting trusts," which respond to the intention of the person who made an apparent gift, and "automatic resulting trusts," which have nothing whatsoever to do with intention, but arise automatically whenever a trustee has a surplus following the failure of an express trust. The second theory is that those resulting trusts which do respond to intention, respond not to the lack of intention to benefit the recipient, but 
to the apparent donor's intention to create a trust for herself or himself. If both theories are correct, then express trusts would have to be classified as those trusts created by intention other than presumed resulting trusts and constructive trusts would mean those trusts created by operation of law other than automatic resulting trusts.

\section{Automatic Resulting TRUSTS}

The theory that there are two different kinds of resulting trusts, responding to two different kinds of events, was invented by Megarry J. to explain the resulting trust which arose in Vandervell v. Inland Revenue Commissioners. ${ }^{29}$ In that case, Mr. Vandervell had granted an option to purchase shares to a company, in trust, but did not specify the objects of that trust. The House of Lords decided that the company held the option on resulting trust for Mr. Vandervell and, therefore, he was liable to pay surtax on the dividends declared on those shares. It was absolutely clear that he did not want to create a trust for himself. With the help of financial advisors, he had attempted to rid himself of his entire interest in the shares for the express purpose of avoiding tax liability on those dividends.

Further litigation involving this option came before Megarry J. in Re Vandervell's Trusts (No. 2). ${ }^{30}$ Megarry J. believed that the resulting trust of an apparent gift was based on the donor's presumed intention to create a trust for herself or himself. Since this was absent in Mr. Vandervell's case, he decided that this resulting trust was something different: an automatic resulting trust, which arose regardless of intention upon the failure of an express trust. Unlike the presumed resulting trust, which was based on the presumed intention to create it, the automatic resulting trust was simply the consequence of failing to dispose of the entire beneficial ownership of an asset. Megarry J. said that it would arise whenever a transfer from A to B was "made on trusts which leave some or all of the beneficial interest undisposed of." ${ }^{31} \mathrm{He}$ continued:

Here B automatically holds on a resulting trust for A to the extent that the beneficial interest has not been carried to him or others. The resulting trust here does not depend on any intentions or presumptions, but is the automatic consequence of $A$ 's failure to dispose of what is vested in him. ${ }^{32}$

There are two difficulties with the theory of the automatic resulting trust. First, there are many cases which show that the settlor's intention to benefit the trustee is very relevant to the question whether or not a resulting trust arises. ${ }^{33}$ As Kekewich J. said in Re West:

[1967] 2 A.C. 291 [hereinafter Vandervell v. IRC].

[1974] 1 Ch. 269.

lbid. at 294.

Ibid.

See, e.g., Fraser v. Fraser, [1937] 1 W.W.R. 91 (Alta. S.C.); Re MacPherson, [1953] O.W.N. 663 (Ont. C.A.); Moffit v. Moffit, supra note 27; Re Walker (1970), 13 D.L.R. (3d) 688 (Ont H.C.). 
It is impossible to say that because property is given to persons as trustees they therefore take no beneficial interest. That is contrary to all experience of the construction of wills, there being many instances of trustees taking beneficially. Nevertheless, there is a presumption that a gift in trust is not a beneficial gift. $^{34}$

Cases like these are sometimes overlooked because of an assumption that a trustee's right to retain the surplus means that there is no trust, but a gift to the trustee subject to a condition to use a portion of that gift for the benefit of another. However, as Professor Waters said in the Law of Trusts in Canada, this assumption confuses two separate issues:

It is always open to a settlor to confer a beneficial interest upon the person who is also to be trustee. Often, then, two questions present themselves: is the obligated person a trustee, and if he is a trustee for the purposes of carrying out the obligation concerning the property, is he also to take a beneficial interest in any excess? The apposition has been put in this way: ' $i t$ is rather a gift upon condition than a gift upon trust', but this is somewhat misleading. Certainly one who is found to be a trustee is often found to have been excluded from any beneficial enjoyment, no doubt because the testator did not wish to expose his trustee to any conflict of interest and duty, but such a finding is not automatic. It is not even a presumption; it is simply a matter of construction. The question is what did the testator intend should happen to moneys left over when the trust purposes have been fulfilled. ${ }^{35}$

The second difficulty with the theory of automatic resulting trust is the notion that it is merely the automatic consequence of a settlor's failure to dispose of the entire beneficial ownership of the trust assets. This cannot be reconciled with the way in which resulting trusts and other equitable property rights function. The resulting trust creates a new equitable property right for the settlor, which differs from the property right he or she had before the transfer to the trustee. As a new right, it cannot be explained as the inertia of a pre-existing beneficial interest.

Assume, for example, that you had the legal ownership of an estate and transferred it to me to hold in trust, but failed to specify any valid object for that trust. I became the legal owner of that estate and (assuming that you did not intend to make a gift to me) now hold it on resulting trust for you. You now have an equitable fee simple estate. Before the transfer, you did not have an equitable property right, but had the full beneficial ownership of that estate at law. As Jeffrey Hackney said in Understanding Equity and Trusts:

Ownership at common law is a beneficial interest giving its owner economic advantages. The beneficial owner at common law has no equitable interest. The Chancellor has nothing to do with him; the common law gives him all the protection he requires. But if a jurisdiction-generating fact (fraud, acceptance of the role of trustee etc.) occurs, an equitable interest will be created, and the common law title will be stripped of its economic value and cease to be ownership.... Equity only operates when 
the common law result is unacceptabie. It does not operate over the whole area and for the most part leaves the common law to get on with it. ${ }^{36}$

At the moment you transferred legal ownership of your estate to me, equity responded to your lack of intention to benefit me and created a resulting trust, which carried the beneficial ownership of that estate back to you. However, your legal estate has been replaced by a new equitable estate. As Brennan J. said in D.K.L.R. Holding Co. (No. 2) Pty. v. Commissioner of Stamp Duties, "A transferee does not become a trustee by failing to acquire an interest in the property transferred; a trustee holds on trust only such interest as he acquires. An equitable interest is not carved out of a legal estate but impressed upon it." ${ }^{\text {"37 }}$

Vandervell v. IRC can be explained satisfactorily without resort to the theory of the automatic resulting trust. It is clear that Mr Vandervell did not intend to create a trust for himself, but that is not the event to which the resulting trust responds. His grant of the option to the company in trust for unspecified objects showed that he did not intend the company to have the option for its own benefit. His lack of intention to benefit the company is that which attracts the intervention of equity through the imposition of a resulting trust. If, as argued below, this is also the event which gives rise to the resulting trust of an apparent gift, then there are not two kinds of resulting trusts, but one.

\section{Presumed Resulting Trusts}

There are several respected English judges and lawyers who have expressed the opinion that the presumed resulting trust is based on the presumption that the apparent donor intended to create a trust for herself or himself. ${ }^{38}$ It is suggested here, with great respect, that this theory is incorrect and that the resulting trust arises because the apparent donor did not intend to benefit the recipient.

For very many cases of resulting trust, the choice between these two views will not affect the outcome. If I transfer an asset to you, intending to create a trust for myself, I do not intend to benefit you. However, the converse is not true. I might not intend to benefit you and yet have no intention to create a trust for myself. I might have intended to benefit somebody else, been unaware of the transaction, or simply failed to address my mind to the issue of beneficial ownership. There are cases of resulting trust in which it is clear that the beneficiary of the trust did not intend to create a trust for herself or himself. They cannot be explained on the basis of a presumed intention to create a trust for oneself. However, a resulting trust based on the lack of intention to benefit the recipient can explain all these cases satisfactorily.

(London: Fontana Press, 1987) at 25.

(1982), 149 C.L.R. 431 at 474.

See Megarry J., in Re Vandervell (No. 2), supra note 30; Lord Browne-Wilkinson, in Westdeutsche Landesbank Girozentrale v. Islington L.B.C., [1996] 2 All E.R. 961 at 990-91; W. Swadling, "A New Role for Resulting Trusts?" (1996) 16 Legal Studies 110. 
Ryall v. Ryall ${ }^{39}$ is an early case of resulting trust, which demonstrates the importance of the difference between these two theories. An executor received the assets of the testator's estate and used them to buy land in his own name. After the executor died, the people entitled to legacies under the testator's will sued the executor's heir to compel him to pay their legacies out of the executor's estate. Lord Hardwicke C. declared that the land was held on resulting trust for the testator's estate. This cannot be explained on the basis of an intention to create the resulting trust, since the beneficiaries of that trust were ignorant of the executor's misuse of the estate assets.

This case has been followed in Canada. In Goodfellow v. Robertson, ${ }^{40}$ land belonging to a man suffering from an "unsoundness of mind" was sold and the proceeds were used by his father-in-law to purchase other land. Spragge C. relied on Ryall to hold that the man's mental incapacity would not prevent the creation of a resulting trust in his favour: "it is a trust resulting by operation of law" and, therefore, it was not necessary to show that he had "an assenting mind on his part."4l This would not be true if the resulting trust depended on the intention to create a trust. However, it is consistent with a trust based on a lack of intention to give.

In Merchants Express Co. v. Morton, ${ }^{42}$ assets were stolen from the plaintiff in a train robbery in the U.S. and used to purchase a hotel in Toronto. Spragge V.C. granted an injunction to prevent the defendant from transferring the hotel, relying on "the principle of resulting trust arising from the purchase of property by one with the moneys of another, and upon the principle of the Court following moneys or other property; and fastening upon them in favour of the true owner." 43

In Sharp v. McNeil, ${ }^{44}$ partnership money was used secretly by one partner to buy land in his sister's name. The sister held that land on resulting trust for the partnership. Townshend C.J. said,

The law is not so helpless as to leave the party wronged without a remedy, and it holds the person to whom such a conveyance has been made as a trustee for the rightful owner. In other words a resulting trust follows. ${ }^{45}$

One final example of a Canadian case in which the beneficiary of the resulting trust was unaware of the transaction, and therefore did not intend to create a trust, is $R e$ Kolari. ${ }^{46} \mathrm{~A}$ bank teller stole money from her employer and used it to buy a variety of things, including a car and furniture. She held them on resulting trust for the bank.

(1739), 1 Atk. 59, 26 E.R. 39 [hereinafter Ryall].

(1871), 18 Gr. 572 (Ont. Ch.).

Ibid. at 575 .

(1868), 15 Gr. 274 (Ont. Ch.).

lbid. at 278.

(1913), 15 D.L.R. 73 (N.S.S.C.), affd (1915), 70 D.L.R. 740 (S.C.C.) [hereinafter cited to N.S.S.C.].

Ibid. at 75 .

(1981), [1982] 36 O.R. (2d) 473. 
Stortini D.C.J. said that a "resulting trust arises where property is obtained by fraud or theft. ${ }^{, 47}$

There are other examples which help disprove the theory that resulting trusts arise in response to intentions to create them. However, it is time to ask a basic question. Why would a trust, which is created by intention, be classified as anything other than express? If I transfer a chattel, money, or a bank account to you, with the intention that you hold it in trust for me, I will have created an express trust for myself. If I do the same thing with land, there will be no express trust, since the Statute of Frauds and its descendants require that an express trust of a property right to land be manifest in writing. However, you would hold the land on resulting trust for me, since resulting trusts are exempt from the requirement of writing.

If my orally expressed intention to create a trust for myself is ineffective to produce an express trust, why should it be permitted to take effect as a resulting trust? There is no satisfactory answer to this question if the resulting trust is also responding to my intention to create a trust for myself. This is merely an express trust which is resulting in pattern and there is no reason to dispense with the writing requirement. If I had transferred land to you with the orally expressed intention that you hold it in trust for someone else, there would still be a resulting trust for me. This provides the clue that the resulting trust is responding not to my intention to create a trust, but to something else. Both examples share a common element: my ineffective intention to create an express trust proves that $I$ did not intend to make a gift to you. You have received land at my expense and I did not intend that you should keep that land for your own benefit.

This issue was explored by the English Court of Appeal in Hodgson v. Marks. ${ }^{48}$ The plaintiff was induced to transfer her house to her lodger on the oral understanding that he would hold it in trust for her. Instead, he sold it to the defendant, who was innocent of any wrongdoing, but took title subject to the plaintiff's property rights to the house (since she still lived there). The oral express trust of land was ineffective (under section 53(1) of the Law of Property Act, 1925 $5^{49}$ ), but the lodger and defendant held the land on resulting trust for the plaintiff. The defendant argued that the plaintiff's oral intention to create a trust for herself could not take effect as a resulting trust if it was invalid as an express trust. The court held that the resulting trust was responding not to her intention to create a trust, but to her lack of intention to give. Russell L.J. said:

[T] he evidence is clear that the transfer was not intended to operate as a gift, and, in those circumstances, I do not sce why there was not a resulting trust of the beneficial interest to the plaintiff, which would not, of course, be affected by section 53(1). It was argued that a resulting trust is based upon implied intention, and that where there is an express trust for the transferor intended and declared - albeit ineffectively - there is no room for such an implication. I do not accept that... It would be a strange outcome

49 (U.K.), 15 \& 16 Geo. 5, c. 20. 
if the plaintiff were to lose her beneficial interest because her evidence had not been confined to negativing a gift but had additionally moved into the field forbidden by section 53(1) for lack of writing. ${ }^{\text {so }}$

\section{F. Role of the Presumptions}

The resulting trust arises when someone receives an asset and is not intended to keep it for her or his own benefit. What function do the presumptions of resulting trust and advancement perform in the creation of a resulting trust? The presumption of advancement is straightforward. If the apparent donor is the parent or (perhaps) husband of the donee, it is assumed that the donor intended to make a gift. In other words, the existence of one fact (the relationship between the parties) leads the court to assume that another fact exists (that a gift was intended). The apparent donor (or the person entitled to her or his estate) bears the onus of disproving that he or she intended to give. If successful, a resulting trust will arise as a response to the proven lack of intention to give.

The presumption of resulting trust is slightly more complex. In the century following the execution of most uses of freehold estates by the Statute of Uses, 1535, the court of Chancery began to enforce uses as trusts. ${ }^{51}$ The presumption of resulting trust became part of the modern law of trusts by analogy to the resulting use. As Eyre C.B. said in Dyer v. Dyer:

The clear result of all the cases, without a single exception, is, that the trust of a legal estate ... results to the man who advances the purchase-money. This is a general proposition supported by all the cases, and there is nothing to contradict it; and it goes on a strict analogy to the rule of the common law, that where a feoffment is made without consideration, the use results to the feoffor. It is the established doctrine of a Court of equity, that this resulting trust may be rebutted by circumstances in evidence. ${ }^{52}$

As discussed above, it seems clear that the presumption of resulting use arose from the widespread practice of transferring land to others to hold to the use of the apparent donor. In other words, when the court encountered a transfer of land for no apparent consideration, it would assume that the transferor intended to create a use for herself or himself. By analogy, is the presumption of resulting trust an assumption that the apparent donor intended to create a trust? This is a possibility. When a court encounters an apparent gift (from someone other than a parent or husband), it could assume that the donor intended to create a trust, but failed to do so. A resulting trust would then arise as equity's response to those presumed facts, because they show that the apparent donor did not intend to make a gift. However, there are several good reasons to believe that the presumption of resulting trust is an assumption that the apparent donor did not intend to give. 
The conditions which gave rise to the presumption of resulting use had ceased to exist by the time the presumption of resulting trust had arisen. Before 1535, people would create uses for themselves in order to avoid feudal incidents and to choose the recipients of their land on death. The Statute of Wills, $1540^{53}$ gave people the right to devise most of their land by will and required the recipient to pay feudal incidents as if the land had descended to the heir. The reasons for assuming that an apparent gift of land was intended to be for the donor's own use had disappeared.

Additionally, it seems that the presumption of resulting use had already become a rule of law divorced from the question of whether the apparent donor intended to create a trust for herself or himself. This is illustrated by the fact that, after the Statute of Uses, 1535, an apparent gift of land could still give rise to a resulting use. The statute would execute the resulting use and return the legal estate to the donor, thereby nullifying the transfer. To deal with this problem, gifts of land would be made "unto and to the use of" the donee, to ensure that the legal estate would pass to the donee. ${ }^{54}$ The presumption of resulting use existed even though there was no reason to assume that an apparent donor would intend to create a use which had only one effect: to invalidate the entire transaction.

Although the presumption of resulting trust was created by analogy to the presumption of resulting use, there is no compelling reason to believe that the new presumption is based on the same reasons which had given rise to the old presumption centuries earlier, but which had ceased to operate as justifications for its continued existence. A more coherent position is that the modern presumption of resulting trust is a presumption of the same fact which triggers equity's intervention by way of resulting trust: that the apparent donor did not intend to make a gift. Otherwise, there would be a mismatch between the presumption and the resulting trust itself. For example, if it was proven that the apparent donor lacked mental capacity, this would both rebut the presumption that he or she intended to create a trust and prove the lack of intention to give. In other words, a resulting trust would arise even though the presumption of resulting trust was rebutted.

The true nature of the presumption of resulting trust is revealed by the evidence which confirms or rebuts the presumption. The courts ask whether the apparent donor intended to make a gift and not whether he or she intended to create a trust. For example, in Lattimer v. Lattimer, ${ }^{5 s}$ a mother purchased real property in the joint names of her son and herself. At that time, the presumption of advancement did not apply in Canada to apparent gifts from mothers to their children, so the son bore the onus of rebutting the presumption of resulting trust. The mother had instructed her solicitor to obtain title this way and had executed a mortgage of the property jointly with her son. However, she did not understand what joint ownership meant. Grange J. said, "Having observed both mother and son giving evidence I am satisfied that both

s4 See R. Megarry and H.W.R. Wade, The Law of Real Property, 5th ed. (London: Carswell, 1984) at $470,1167$.

ss

(1978), 82 D.L.R. (3d) 587 (Ont. H.C.). 
could have signed the mortgage without knowing how title was being taken." 56 Her failure to understand the nature of the transaction is evidence that she did not intend to create a trust. However, that was not the issue before the court. The son had the burden of proving that his mother had intended to make a gift, which he could not do.

The presumption of resulting trust is an inference regarding the intention of an apparent donor. Proof of certain facts (that an apparent gift was made by someone who is not the parent or perhaps husband of the donee) leads the court to assume that another fact exists (that the apparent donor did not intend to make a gift). Unless disproved, equity responds to that lack of intention by compelling the donee to hold the apparent gift on resulting trust for the donor. It is important to note that the presumption of resulting trust is an inference concerning the donor's intention, which is drawn in the absence of evidence of that intention. If the donor's intention is proved, there is no room for the presumption of resulting trust or advancement. The resulting trust then responds (or not) to the facts as proven.

\section{G. ROLE OF INTENTION}

As discussed above, the intention of the donor or settlor plays a negative role in the creation of resulting trusts. It is the absence of intention to benefit the recipient which attracts the intervention of equity by way of resulting trust. The central importance of intention in the law of resulting trusts has led to confusion. As Waters said, "The nature of the resulting trust is still the subject of some discussion...; is it a trust which is concerned with the intent of the transferor of the property, or does it describe a trust obligation imposed by law?"57 The resulting trust is both. It is not created directly by intention, but arises by operation of law in response to the fact that the donor or settlor did not intend to benefit the recipient. As Birks said, "There is a fine but important distinction between intent conceived as creative of rights, as in an express trust or a contract, and intent conceived as a fact which, along with others, calls for the creation of rights by operation of law." 58

Brown v. Brown ${ }^{59}$ demonstrates the negative role which intention plays in this area of law. Money from the sale of a mother's house was used to purchase another house in her sons' names. It was not clear whether the mother was aware that she did not have legal title to the new house. Gleeson C.J. said that the parties had not "thought through the consequences of their transaction, or made any agreement about title to the land that was being purchased" and that the mother "did not have any intention concerning the potential ownership of the" house. ${ }^{60}$ The fact that she had not given any thought to the issue of beneficial ownership rebutted the presumption of advancement. As Gleeson

\footnotetext{
s6. Ibid. at 589.

37 Supra note 35 at 18.

s* Supra note 15 at 65.

s9 $\quad$ (1993), 31 N.S.W.L.R. 582 (C.A.).

(x) Ibid. at 586-87.
} 
C.J. said, it proved that she "did not intend to make a gift (or a loan) to her sons." Therefore, they held the house on resulting trust for her.

In Brown v. Brown, Kirby P. dissented on the basis that the presumption of advancement had not been rebutted, since there was no evidence "that the mother positively intended not to make a gift to her sons." ${ }^{62}$ This is a further illustration of the negative role of intention in this situation. The presumption of advancement is an assumption that an apparent donor intended to give. Any evidence which shows that he or she did not in fact form that intention (including evidence of ignorance, incapacity, or mere inadvertence) will rebut that presumption. The resulting trust responds, not because the donor had a positive intention not to benefit the donee, but because he or she lacked the intention to confer that benefit. There is a subtle difference between the positive "intended not" and the negative "not intended." However, it is an important difference which allows the resulting trust to respond in cases where assets have been obtained at the expense of a person who was unaware of the transaction or simply failed to think about it at all.

\section{H. UNJUST ENRICHMENT}

As discussed above, a resulting trust arises when someone transfers an asset to, or purchases an asset for, another person and does not intend to benefit that other person. It should now be possible to classify that event in a way which allows it to be compared to other events which give rise to personal or property rights. Birks classified the events which give rise to legal rights into four categories: consent, wrongs, unjust enrichment, and other events. ${ }^{63}$ The event which produces resulting trusts belongs in the third category, unjust enrichment.

Unjust enrichment was defined by the Supreme Court of Canada in Pettkus v. Becker. ${ }^{64}$ Dickson J. said that "there are three requirements to be satisfied before an unjust enrichment can be said to exist: an enrichment, a corresponding deprivation and absence of any juristic reason for the enrichment." ${ }^{165}$ These requirements are met in every case of resulting trust.

\section{ENRICHMENT}

The subject of a resulting trust is always some asset which the resulting trustee has received, such as a property right to land or goods or a personal right to a sum of money in a bank account. There is no doubt that this constitutes an enrichment. It falls within the definition given by the American Law Institute in the Restatement of the

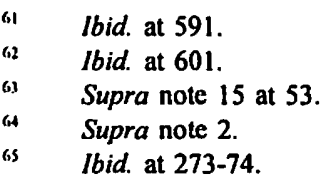


Law of Restitution: "A person confers a benefit upon another if he gives to the other possession of or some other interest in money, land, chattels, or choses in action." 66

\section{CORRESPONDING DEPRIVATION}

There are two ways in which the enrichment of a resulting trustee can correspond to the deprivation of the apparent donor (or settlor) entitled to the benefit of that trust. The donor may transfer an asset directly to the resulting trustee or may purchase an asset for her or him. In the former situation, there is no difficulty establishing the connection between enrichment and deprivation, since the donor was deprived of the very asset which constitutes the enrichment. The latter situation is only slightly more complex.

Suppose, for example, that you paid a vendor to transfer a house to me. I am enriched, by the receipt of a house, and you have been deprived of the purchase price. My enrichment is not at the expense of the vendor, who is neutral in the story, having received valuable consideration in exchange for her or his property right to the house. Although my enrichment and your deprivation consist of different assets, it is clear that wealth has flowed from you to me.

The only possible wrinkle occurs in cases where the purchase price paid for the asset is less than the full market value of that asset. Returning to our example, if the price accepted by the vendor was not received as the full purchase price for the house, it may be that you and the vendor are both apparent donors and, therefore, I should hold it on resulting trust for both of you in proportion to your contributions. However, if the purchase price was accepted by the vendor in good faith as the full consideration for the transfer, then he or she remains neutral in the story. You have made a good bargain. The enrichment of the resulting trustee is not at the vendor's expense, since the benefit of the good bargain belonged to you. You might have taken the transfer for yourself and, therefore, have been deprived of the house and not merely the price paid for it.

\section{ABSENCE OF JURISTIC REASON}

The absence of juristic reason for the enrichment of the resulting trustee is established by proof or presumption of the fact that the apparent donor or settlor did not intend to benefit the trustee. It is similar to cases where an enrichment is unjust because it was transferred by mistake, under duress or undue influence, or for a consideration which failed. In all these situations, the person deprived of the enrichment can say that he or she did not intend to benefit the recipient. The intention to confer the benefit was vitiated or impaired in some way, conditional upon the happening of certain events, or wholly absent. Birks grouped these "factors rendering an enrichment "unjust" under the heading "non-voluntary transfer":

Where there is 'a non-voluntary transfer', so that the circumstance calling for restitution is 'a factor negativing voluntariness', the explanation of the response is always reducible in the simplest terms to 
the statement that the plaintiff did not mean the defendant to have the money in question or the other enrichment, whatever it might be. ${ }^{.7}$

The resulting trust responds to this category of unjust enrichment. It should be noted that this conclusion does not change the resulting trust. It merely helps us to understand that trust better and ensure that it is applied and developed coherently. The uncertainty over the events which give rise to resulting trusts has impeded progress in this area of law in recent years. Another benefit of this conclusion is that it allows the resulting trust to be compared to other responses to unjust enrichment. For example, a mistaken payment gives rise to a right to restitution of unjust enrichment because the payer did not intend to benefit the payee. Can the resulting trust also respond to this event? This issue is discussed below.

\section{J. RESTITUTION}

Regardless of the nature of the event which gives rise to the resulting trust, it seems clear that the trust is restitutionary. As Waters said, "it readily appears to be no more than a device for the restoring of property to the person with the best claim." ${ }^{68}$ Birks said, "Restitution is the response which consists in causing one person to give up to another an enrichment received at his expense or its value in money." ${ }^{69}$ All resulting trusts meet this definition since they cause the beneficial ownership of an asset received by the resulting trustee to be given up to the person who transferred that asset to the trustee or paid the purchase price for it.

As discussed above, all resulting trusts arise to effect restitution of unjust enrichment. However, they would still be restitutionary even if they arose because the apparent donor intended to create a trust or because the settlor failed to dispose of her or his beneficial ownership of the property. In other words, even if Megarry J.'s theories of presumed and automatic resulting trusts were correct, those trusts would be restitutionary. However, they would be examples of rights to restitution generated not by unjust enrichment, but by consent and by the passive preservation of pre-existing property rights, respectively. As Birks said:

If we classify causative events as manifestations of consent, wrongs, unjust enrichment, and miscellaneous other events, and if we free the notion of restitution (giving up a gain to another) from the false association with any one event, it will turn out that restitution can arise from every event so named. I can contract to give up a gain, I may have to give up a gain because of a wrong, I may have to give up a gain which is an unjust enrichment, and I can be compelled to give up a gain by other facts, as for instance a judgment."

There is no need to explore this particular issue further here, because all resulting trusts arise to effect restitution of unjust enrichment. 


\section{RESPONSES TO UNJUST ENRICHMENT}

Although restitution is a response to a variety of events, including unjust enrichment, it appears that the converse is not true. Unjust enrichment produces only one response: restitution of that enrichment or its value in money. This is dictated by the nature of unjust enrichment. The liability arises solely because the defendant has received a benefit which should not have been received or kept for her or his own benefit. There has been no duty breached, promise made, or reasonable expectation induced. The only response which can be justified by the receipt of a benefit is the liability to give up that benefit or its value in money.

All rights to restitution are (a) either legal or equitable and (b) either personal or property. At common law, the normal response to unjust enrichment is a personal right to be paid the value of the enrichment. A debt arises by operation of law for the value of the services, goods, use of land, or money which constitutes that enrichment. Unjust enrichment can also generate property rights at common law, but this happens much less frequently. For example, a vendor might be entitled to rescind a sale induced by fraud and thereby recover legal title to the asset sold. ${ }^{\prime \prime}$

Personal rights to be paid the value of unjust enrichment are also created in equity. For example, the receipt of assets misappropriated from a corporation, partnership, or trust can create an equitable debt for their value. ${ }^{72}$ However, restitution is often achieved in equity through the creation of property rights, by way of rectification, rescission, lien, or trust.

Rectification is available to correct mistakes in transactions and rescission is available to undo transactions which were induced by mistake, duress, undue influence, etc. These equitable remedies lead to personal rights to restitution when they entitle a party to escape personal liabilities or be paid the value of unjust enrichment. ${ }^{73}$ They can also generate property rights when a party is thereby entitled to recover a specific asset. For example, in Blacklocks v. J.B. Developments (Godalming), ${ }^{74}$ the plaintiff sold land and, by mistake, included more land in the conveyance than the parties intended. He was entitled to rectify the conveyance and therefore had a property right to the extra land mistakenly conveyed.

Equitable liens arise by operation of law as security for the performance of a related personal obligation. Where that obligation is restitution of the value of unjust enrichment, the lien arises usually because the enrichment is, or has been used to pay for, the improvement or preservation of the asset subject to the lien. ${ }^{75}$ The purchaser's lien operates somewhat differently. It secures the obligation to make restitution of the

See Car \& Universal Finance Co. v. Caldwell, [1965] I Q.B. 525 (C.A.).

See Citadel General Assurance Co. v. Lloyds Bank Canada (1997), 152 D.L.R. (4th) 411 (S.C.C.); M. Bryan, "The Receipt-Based Constructive Trust: A Case Study of Personal and Proprietary Restitution in the Supreme Court" (1999) 37 Alta. L. Rev. at 73.

See, e.g., Newbigging v. Adam (1886), 34 Ch. D. 582 (C.A.).

[1982] Ch. 183 [hereinafter Blacklocks].

See Canada Permanent Trust Co. v. MacLeod (1979), 103 D.L.R. (3d) 444 at 458. 
purchase price when a contract for the sale of land will not be performed. ${ }^{76}$ The unjust enrichment cannot be traced into the land to which the purchaser's lien attaches. However, the vendor is entitled to retain the land free of the constructive trust which arose in favour of the purchaser when the contract of sale was made. It might be said that the vendor would be unjustly enriched if he or she was entitled to recover the full beneficial ownership of the land without making restitution of the purchase price due to be refunded to the purchaser.

A trust is not a security right, like an equitable lien, but the beneficial ownership of the assets subject to the trust. Most trusts are express, arising by consent. Others are constructive, arising to effect restitution of assets acquired in breach of duty or to perfect detrimentally relied upon intentions to benefit others. ${ }^{77}$ Trusts can also arise in response to unjust enrichment. As discussed above, all resulting trusts respond to unjust enrichment. The difficulty is knowing when and why unjust enrichment gives rise to a trust, rather than (or in addition to) some other legal or equitable right to restitution.

\section{A. TRUSTS OF UNJUST ENRICHMENT}

A trust cannot arise in response to unjust enrichment unless that enrichment is an asset capable of being the subject of the trust. Again, this is dictated by the nature of unjust enrichment. The only possible response to unjust enrichment is restitution. The law can intervene to require the defendant to give up the enrichment itself or its value in money. Since the trust is an equitable property right, it must cause the defendant to give up the beneficial ownership of the enrichment itself. Therefore, when the enrichment is a service or an asset that did not survive (such as goods consumed), restitution is limited to a personal right to be paid the value of the enrichment. A trust of the enrichment is not possible. Conversely, any trust which attaches to something other than the unjust enrichment is not restitutionary.

This proposition should be regarded as a simple truth. However, it is placed in doubt by a series of family property cases decided by the Supreme Court of Canada. They suggest that a trust can arise to effect restitution of unjust enrichment even though the enrichment consists of services and the subject of the trust is not the enrichment. For example, in Peter v. Beblow, ${ }^{78}$ the plaintiff and defendant lived together in a house which the defendant owned when they met. The plaintiff looked after the house and garden, chopped wood, shovelled snow, and helped raise the defendant's children. The court decided that those services had unjustly enriched the defendant in the sum of $\$ 25,200$. This was calculated by valuing the plaintiff's services at $\$ 350$ per month for 12 years and reducing the total by half to account for the accommodation and food which the defendant had provided to the plaintiff and her children. The court declared B.R.M. Enterprises (1978), 88 D.L.R. (3d) 87 (B.C.S.C.).

$7 \quad$ See Elias, supra note 6.

78 [1993] 1 S.C.R. 980, 101 D.L.R. (4th) 621 [hereinafter cited to D.L.R.]. 
that the plaintiff was entitled to a constructive trust of the full value of the defendant's house, which was worth $\$ 23,200$.

The trust of the house may be entirely justified in this situation, but it is not restitution of unjust enrichment. It did not cause the defendant to give up that enrichment or its value in money. The enrichment consisted of services which did not produce a lasting asset and the trust attached to an unrelated asset. There were only two possible connections between the plaintiff's services and the trust of the house. First, the market value of the house coincided roughly with the net unjust enrichment of the defendant (as valued by the court). Secondly, it might be said that the plaintiff only provided those services to the defendant because she expected to receive an interest in that house. Neither connection makes the trust restitutionary.

\section{CoINCIDENCE of VAlue}

The trust of an asset is not restitutionary just because the asset, by coincidence, equals the value of an unjust enrichment of the trustee. It is true that the trust can operate to fulfil the trustee's obligation to make restitution of that value, but the trust cannot be explained as a direct, restitutionary response to that enrichment. There is no reason why a personal right to be paid the value of unjust enrichment should produce a property right to an unrelated asset. Otherwise, every creditor ought to be entitled to claim a trust over any of the debtor's assets which happened to be equal in value to the debt. There is nothing special about debts created by unjust enrichment which sets them apart from debts created by consent, wrongdoing, or other events.

It is sometimes suggested that a trust of the house is justified when the asset happens to equal the value of the unjust enrichment because the defendant was able to maintain, improve, or pay for the mortgage of that house because he or she did not have to pay the plaintiff for the services which constitute the unjust enrichment. However, this does not connect the house to that unjust enrichment in any meaningful way. The same could be said of all the defendant's assets and debts. If property rights could be created in this fashion and, for example, I paid an instalment due on my car loan instead of my rent, why would my landlord not acquire a property right to my car? If I paid my rent instead of the car loan, why would the lender not acquire a property right to my leasehold estate? Taking this suggestion to its logical conclusion would convert all debtors into trustees of all their assets for their creditors.

It is true that a failure to pay a debt can lead to the creation of property rights to unrelated assets through execution. The creditor might obtain a judgment for the debt and instruct the sheriff to seize the debtor's assets and sell them to pay the judgment debt. However, liability to execution is a general and justifiable limit on ownership. ${ }^{79}$ It is carefully regulated by the judicial process and by provincial statutes which exempt necessaries from execution. 
Normally, the law respects our freedom of choice. It allows us to decide how we will pay our debts. We are free to dispose of the assets we value least to raise the money needed to pay our creditors. It is only when we choose not to pay our debts that the law permits our creditors to override that choice and take our assets through judgment and execution. There is nothing special about debts created by unjust enrichment which takes them outside this framework and justifies the creation of trusts over unrelated assets by operation of law. As Professor Birks said in "Proprietary Rights as Remedies":

A judgment for the surrender of items of property inflicts loss, as does a money judgment, but, unlike a money judgment, also entangles itself in the complexities both of unwanted consequences for third parties and of individual economic priorities. The latter point is important and often neglected. Taking money from people makes them worse off and narrows their options, taking specific things is a more erratic instrument of justice, because of their subjective value: the same 'adjustment' will cause vastly different degrees of pain, depending on the sentiments and tastes of the loser. ${ }^{80}$

\section{REASONABLE EXPECTATIONS}

In Peter v. Beblow, the only possible connection between the plaintiff's services and the defendant's house was the fact that the plaintiff provided those services with the reasonable expectation of receiving an interest in that house. This was indeed the factor which led to the creation of the trust in that case. As Cory J. said, it is not "unreasonable for the party providing the domestic labour required to create a home to expect to share in the property of the parties when the relationship is terminated."

This principle was established by the Supreme Court of Canada in Pettkus v. Becker, where Dickson J. said,

[W] here one person in a relationship tantamount to spousal prejudices herself in the reasonable expectation of receiving an interest in property and the other person in the relationship freely accepts benefits conferred by the first person in circumstances where he knows or ought to have known of that reasonable expectation, it would be unjust to allow the recipient of the benefit to retain it. ${ }^{\text {s2 }}$

In Sorochan v. Sorochan, ${ }^{83}$ Dickson C.J. confirmed that this was the basis of the trust which arises in this situation. He said that "in assessing whether a constructive trust remedy is appropriate, we must direct our minds to the specific question of whether the claimant reasonably expected to receive an actual interest in property and whether the respondent was or reasonably ought to have been cognizant of that expectation." ${ }^{34}$ 218. 
The creation of a trust by operation of law can be justified where the beneficiary of that trust reasonably expects to receive a property right to the subject of that trust and, in reliance on that expectation, unjustly enriches the trustee. However, the presence of unjust enrichment does not make a trust restitutionary if the trust does not cause the defendant to give up the enrichment. It fulfils the beneficiary's reasonable expectation and is, therefore, perfectionary. ${ }^{85}$

Unfortunately, this means that the family property cases, which involve both unjust enrichment and constructive trusts, tell us very little about when and why a trust should arise to effect restitution of unjust enrichment. The plaintiff's reasonable expectation of receiving a property right connects the enrichment to the trust in those cases, but is missing in most cases of unjust enrichment. For example, when money is paid by mistake, the payer unjustly enriches the recipient with no expectation of thereby receiving a property right to any of the recipient's assets. Although there is no reasonable expectation which the law can perfect, this does not preclude the creation of a trust to effect restitution of that unjust enrichment.

\section{B. Property Rights Created By UnJust EnRichment}

The Supreme Court of Canada has not yet answered the essential questions concerning property rights created by unjust enrichment. First, if the defendant is unjustly enriched at the plaintiff's expense, should the plaintiff's right to restitution be limited to a personal claim for the value of the enrichment or should it be a property right to the enrichment instead of, or in addition to, the personal claim? Second, if the plaintiff is entitled to a property right to the enrichment, should it be a lien, which secures the performance of the defendant's obligation to pay for the value of the enrichment, or should it be a trust, which transfers the beneficial ownership of the enrichment to the plaintiff? Third, if the plaintiff is entitled to a trust of the unjust enrichment, is that trust constructive or resulting? There are no clear answers to these questions. All that is possible, at this stage in the development of the Canadian law of unjust enrichment, is to suggest coherent ways in which these questions might be answered.

People, with the aid of legal advice, ought to be able to identify their legal rights and obligations. The particular legal response to a particular event, whether that event is a promise, a breach of duty, unjust enrichment, or something else, ought to be identifiable without having to resort to litigation. The only sure way to progress towards this goal is to link the response to the event. The law does this already with contracts and torts. In most cases, the consequences of making a contract or breaching a legal duty are readily predictable. The same level of certainty must be achieved in the law of unjust enrichment.

The particular response to unjust enrichment should depend upon the nature of that unjust enrichment. In other words, the plaintiff's rights to restitution should be dictated by the event. There are only two ways in which one unjust enrichment can be 
distinguished from another: by the nature of the enrichment or by the nature of the factor which renders that enrichment unjust (the reason why there is no juristic reason). The method of restitution must depend on one or both of these variables.

\section{THE NATURE OF THE ENRICHMENT}

The starting point is straightforward. As discussed above, if the enrichment is not (or did not survive as) an asset capable of being subject to property rights, then the plaintiff's right to restitution must be a personal claim for its value. However, if the enrichment is a surviving asset, that does not necessarily mean that restitution should be effected by means of a property right, nor does it indicate whether the property right, if any, should be a lien or a trust. Is it possible to answer these questions by reference to the nature of the asset which constitutes the enrichment?

In Constructive Trusts, Malcolm Cope suggested that a trust should be used to effect restitution of unjust enrichment only where the enrichment is land or a rare chattel. ${ }^{86}$ In other cases, a personal claim for the value of the enrichment would be an adequate substitute for the recovery of the enrichment itself. This is one of the factors which indicates whether a contract of sale is specifically enforceable. Cope's suggestion deserves consideration. However, its adoption would change the law. There are a number of cases in which the plaintiff was entitled to specific restitution of ordinary chattels or a fund of money. ${ }^{87}$ Also, as discussed below, there are good reasons for believing that rights to restitution of ordinary goods and money should, in some cases, be proprietary.

Another method of distinguishing one enrichment from another is by whether it is the asset which the defendant initially received at the plaintiff's expense, or an asset into which the initial unjust enrichment can be traced. A trust is easier to justify in the former situation. Where the defendant is unjustly enriched by the receipt of an asset, the plaintiff's right to restitution arises because the defendant should not keep that asset for her or his own benefit. Allowing the plaintiff to choose whether to take the asset itself or its value in money does not interfere greatly with the defendant's freedom of choice, since her or his retention of the benefit of that asset is the unjust enrichment. A trust of that asset is an effective method of restoring the status quo ante. Giving up the asset itself merely returns the defendant to the position he or she was in before the unjust enrichment.

Where the enrichment initially received from the plaintiff has been used to improve, maintain, or purchase another asset, different considerations arise. Although the initial enrichment is no longer part of the defendant's assets, a property right is possible because the value received at the plaintiff's expense can be traced into another asset. The plaintiff's connection to the substitute asset is based solely on the defendant's use

(Sydney: Law Book Co., 1992) at 487.

"7 See, e.g., Clough v. London \& N.W. Rail Co. (1871), L.R. 7 Exch. 26; Lady Hood of Avalon v. MacKinnon, [1909] 1 Ch. 476; Newtons of Wembley, Ltd. v. Williams, [1964] 3 All E.R. 532 (C.A.); Re Kolari, supra note 46; Gibbon v. Mitchell, [1990] 3 All E.R. 338. 
of the plaintiff's value. It is clear that restitution can be effected by means of a trust of the substitute asset. ${ }^{88}$ However, where the property right depends on tracing value, there needs to be some explanation of the reason why the plaintiff has anything more than a right to be paid that value.

Property rights to the substitute asset can be justified for at least two reasons. First, the plaintiff's property right to the asset initially received by the defendant would be fleeting if any dealing with that asset destroyed the property right. A transaction as commonplace as a bank deposit operates to exchange one asset for another. Few restitutionary property rights would survive if they could not be transferred from one asset to another through the process of tracing. The law has long recognized this practical reality and permitted property rights to be sustained in this way. ${ }^{89}$

Second, where the value initially received at the plaintiff's expense continues to survive as part of an identifiable asset belonging to the defendant, the plaintiff should have a property right to that asset to preserve the priority of her or his claim over the defendant's other creditors. The unjust enrichment still survives as an increase to the defendant's wealth and there is no compelling reason why that value should be used to satisfy other claims against the defendant. For example, if you paid me by mistake while I was insolvent, most people would agree that I should be under a duty to return the money and not use it to pay my other creditors. In other words, I should hold the money received in trust for you. ${ }^{90}$ If that is true, then your property right should not come to an end merely because I deposit the money in my bank account, or use it to purchase another asset. So long as the value I received from you traceably survives as all or part of an asset in my hands, I should not be permitted to use that value to pay other creditors. Your property right to that asset will leave my creditors no worse off than if you had not paid me by mistake.

The arguments in favour of raising a property right to a substitute asset into which the plaintiff's value can be traced, as a method of restitution of unjust enrichment, do not indicate whether that property right should be a lien or a trust. There are cases demonstrating that both are possible. Does the nature of the enrichment dictate the appropriate response? There is an important distinction between cases where the defendant used the plaintiff's value to improve or maintain an existing asset and those in which the defendant used that value to purchase a new asset. In the former situation, the proper response is the creation of an equitable lien to secure the defendant's personal obligation to pay for the plaintiff's value which traceably survives as part of that asset. Since the plaintiff is not a beneficial owner of that asset, but has only a security right, the defendant is free to make restitution by disposing of other assets which the defendant values less. It is only when the defendant chooses not to fulfil that obligation (or cannot due to insolvency) that the plaintiff is permitted to override the

See, e.g., Sharp v. McNeil, supra note 44 and accompanying text.

") See Taylor v. Plumer (1815), 3 M. \& S. 562, 105 E.R. 721; L.D. Smith, The Law of Tracing (Oxford: Clarendon Press, 1997).

ॠ1 See In re Berry (1906), 147 F. 208 (C.A.). 
defendant's freedom of choice and enforce her or his security rights to the improved or maintained asset.

Where the plaintiff's value has been used by the defendant to purchase a new asset, a trust is possible. However, this does not mean that a trust should arise in every case. For example, suppose that I paid $\$ 5,000$ to you by mistake and you used that money as part of the $\$ 100,000$ you paid for your new home. Should I be entitled to an equitable lien on your home for $\$ 5,000$ (plus interest) or the beneficial ownership of 5 percent of your home as an equitable tenant in common under a trust? If you were unaware of my mistake and your obligation to make restitution of unjust enrichment, there is no compelling reason why your decision to use my value to purchase your home should restrict your freedom of choice to make use of other assets you value less to fulfil that obligation. Also, there is no compelling reason why I should be entitled to share any increase in the value of that asset as a result of improvements to your home or inflation of land values. ${ }^{91}$ There is nothing inconsistent about the view that I should be entitled to a trust of the asset that you initially received at my expense (the $\$ 5,000$ ), but only a lien over the substitute asset into which that value can be traced (your home).

I argued previously that a lien is more intrusive (and therefore less desirable) than a trust in cases where the asset drops in value and the defendant is unable to pay for the unjust enrichment with other assets. ${ }^{92}$ Continuing with our example, if the market value of your house dropped to $\$ 80,000$, a trust of 5 percent of the home would be worth $\$ 4,000$, but a lien for $\$ 5,000$ would be more than 6 percent its value. In other words, the lien has the potential to attach to your value as well as mine. However, there is a strong counter-argument which favours the lien in this situation. Your obligation to pay for the value of the unjust enrichment decreases as that enrichment is dissipated without benefit to yourself, because you are thereby entitled to the defence of "change of position." Since my lien merely secures the performance of your obligation to make restitution, it too will decrease in value. The loss in value of your home should count as a change of position and a partial defence to my claim.

Different considerations apply when the defendant is aware of the unjust enrichment. A trust of an asset purchased with that enrichment is a justifiable limitation on the defendant's freedom of choice. Since the defendant knowingly used the plaintiff's value to acquire the new asset, he or she cannot complain about the plaintiff's beneficial ownership of that asset or her or his right to share in any increase in its value. It appears that in most (if not all) cases of resulting trust, where the subject of the trust was not the asset initially received by the trustee, but a substitute asset into which its value could be traced, the trustee was (or ought to have been) aware of the beneficiary's entitlement to that value.

If the defendant has knowingly used the plaintiff's value to improve or maintain an existing asset, any property right to restitution of unjust enrichment should be a lien and

See In re Tilley's Will Trusts, [1967] Ch. 1179.

42 "Tracing, Trusts, and Liens" (1997) 11 Trust Law International 86 at 88-89. 
not a trust. It must be remembered that the right is created by unjust enrichment and not wrongdoing. This does not justify a transfer to the plaintiff of the beneficial ownership of assets which the defendant acquired independently of that enrichment. It might be possible for the plaintiff to claim a trust of the asset on the basis that the defendant should not be allowed to profit from wrongdoing. However, this would be a constructive trust created by wrongdoing and not by unjust enrichment.

There may be a problem in cases where the value of the plaintiff's improvement to the defendant's asset is greater than the value of the asset itself. If the asset is a chattel, it may be possible to say that the improvement is the main chattel to which the asset has been attached (as an accession). Viewed in that light, it is a case in which the defendant has acquired an asset at the plaintiff's expense and not merely improved an existing asset. A trust of that asset is then possible as a response to unjust enrichment. This approach cannot be used in relation to improvements to land, since land is always the primary asset in which an improvement will lose its separate identity (as a fixture). This is true even if the improvement is a thousand times more valuable than the land (e.g., an office tower constructed on a vacant lot). In the absence of wrongdoing, any property right to restitution of unjust enrichment should be a lien over the land for the value of the improvement (even though the lien might equal or exceed the total value of the improved land). The defendant in that situation should have the opportunity to satisfy the plaintiff's claim using other assets, if possible.

To summarize, a trust is an appropriate response to unjust enrichment where the enrichment subject to the trust is an asset:

(a) received by the defendant at the plaintiff's expense, or

(b) purchased by the defendant, using value obtained at the plaintiff's expense, at a time when the defendant was aware of, or ought to have been aware of, the plaintiff's right to restitution of that value.

A lien is an appropriate response where the value obtained at the plaintiff's expense can be traced to, and survives in, the asset subject to the lien, because it was used:

(a) to improve or maintain the value of the asset, or

(b) to purchase the asset when the defendant was unaware of the plaintiff's right to restitution of that value.

If the unjust enrichment does not survive as value traceable into specific assets belonging to the defendant, there is no justification for anything other than a personal right to restitution of the value of the enrichment received.

\section{THE ABSENCE OF JURISTIC REASON}

If an unjust enrichment does meet the minimum requirements for a trust suggested above, should the plaintiff be entitled to a trust of that enrichment? It has been 
suggested that this depends on the reason why the enrichment is unjust (or, in Canadian terms, why there is no juristic reason for the enrichment). Lord Millett argued, in "Restitution and Constructive Trusts," ${ }^{93}$ that a trust is appropriate if the plaintiff had no intention to benefit the defendant whatsoever, but not if the plaintiff's intention to benefit the defendant was merely vitiated or qualified. The two traditional categories of resulting trust are situations in which the plaintiff had no intention to benefit the defendant, because it is proved or presumed in each case that a gift was not intended. Also meeting this requirement are cases in which the plaintiff was unaware of the loss of value or helpless to stop it, such as where the plaintiff's assets have been misappropriated by the plaintiff's agent, director, or officer. ${ }^{94}$

Lord Millett would say that a trust is not appropriate in cases where the unjust enrichment consisted of an asset transferred by mistake, under duress or undue influence, or for a consideration which failed. In these cases, the plaintiff intended to benefit the defendant and is entitled to restitution because that intention was vitiated or qualified in some way. Although that vitiation or qualification makes the enrichment unjust, it is not sufficient to attract the intervention of equity by way of a trust. ${ }^{95}$

As always, Lord Millett's opinions on this subject deserve close attention and great respect. A coherent line can be drawn between an absence of intention to benefit the defendant and other factors which make an enrichment unjust. Property rights to restitution could be restricted to unjust enrichments in the former category, leaving plaintiffs in other situations with only a personal right to be paid the value of the unjust enrichment. However, that is not the line the law has drawn, nor is it the line which Lord Millett intends to draw. There are numerous cases in which a plaintiff was entitled to recover a specific asset transferred by mistake or under undue influence. ${ }^{96}$

The distinction between cases where the plaintiff's intention to benefit the defendant is absent and those in which it is merely vitiated is, for Lord Millett, relevant to the question of when the plaintiff's property right arises. Where that intention is absent, a trust arises when the defendant first receives title to the asset at the plaintiff's expense. Where it is vitiated, the trust arises only when the plaintiff elects to rectify or rescind the transaction and recover the asset from the defendant. Lord Millett said, in "Restitution and Constructive Trusts":

[T]he beneficial interest passes, but the plaintiff has the right to elect whether to affirm the transaction or rescind it. If he elects to rescind it, it is usually assumed that the beneficial title revests in the plaintiff, and the authorities suggest that it does so retrospectively. But the recipient cannot anticipate his decision. Pending the plaintiff's election to rescind, the recipient is entitled, and may be bound, to treat the payment as effective.... In the meantime, the plaintiff's right to rescind has been classified as a mere equity. Although this has been criticised there is much to commend it. Pending rescission the 
transferee has the whole legal and beneficial interest in the property, but his beneficial title is defeasible. $^{\text {? }}$

This framework could well provide the basis for building a coherent body of law regarding property rights to restitution of unjust enrichment. However, it is not yet the law. There is a long line of authority which says that a plaintiff in this position has an equitable property right to an asset recoverable through rectification or rescission, which exists before the plaintiff takes any steps to rectify or rescind the transaction. ${ }^{98}$ Some cases call that right a trust, while others refer to it unhelpfully as a "mere equity."

What should the law be? There are several arguments in favour of the proposition that a trust arises when the defendant is unjustly enriched by the receipt of an asset, regardless of the particular reason why that enrichment is unjust. Where that reason is some vitiation of the plaintiff's intention to benefit the defendant (such as mistake, duress, or undue influence) and the plaintiff is thereby entitled to rectify or rescind the transaction and recover title to that asset, the defendant should hold that asset on trust for the plaintiff until title is recovered. If the right to rectify or rescind is lost for any reason (such as a sale of the asset to a bona fide purchaser), the trust of the asset would come to an end (although a trust of the sale proceeds might then be possible).

The plaintiff's right to rectify or rescind the transaction arises because the defendant is unjustly enriched at her or his expense (and not the other way around). The defendant is unjustly enriched by the receipt of the asset, which he or she was not intended to have or keep, and it is that event which should give rise to a trust as well as the right of rectification or rescission. As a general principle, whenever a defendant can be compelled by a court of equity to transfer an asset to the plaintiff, the plaintiff is regarded as the equitable owner of that asset. In other words, the defendant holds the asset in trust for the plaintiff. This is the principle which lies behind the constructive trust which arises on the making of a specifically enforceable contract for the sale of land.$^{99}$ It also explains why the recipient of a bribe, in breach of fiduciary duty, holds that bribe on constructive trust for the victim of that breach. As Lord Templeman said in A.G. Hong Kong v. Reid:

As soon as the bribe was received it should have been paid or transferred instanter to the person who suffered from the breach of duty. Equity considers as done that which ought to have been done. As soon as the bribe was received, whether in cash or in kind, the false fiduciary held the bribe on a constructive trust for the person injured. ${ }^{100}$

98 See Stump v. Gaby (1852), 2 De G.M. \& G. 623, 42 E.R. 1015; Leuty v. Hillas (1858), 2 De G. \& J. 110, 44 E.R. 929; Gresley v. Mousley (1859), 4 De G. \& J. 78, 45 E.R. 31; Dickinson v. Burrell (1866), L.R. 1 Eq. 337; Melbourne Banking Corp. v. Brougham (1882), 7 App. Cas. 307 (P.C.); In re Garnett (1886), 33 Ch. D. 300 (C.A.); Craddock Brothers v. Hunt, supra note 96; Latec Investments v. Hotel Terrigal Pty. (1965), 113 C.L.R. 265 (H.C.A.); Blacklocks, supra note 74. 
This reasoning applies to someone who receives an asset transferred by mistake, under duress or undue influence, etc. Although the recipient of the asset has not breached a duty to the plaintiff, the law regards the receipt (or retention) of that asset as an unjust enrichment. It would seem odd if the defendant was unjustly enriched by the receipt of the asset and yet under no duty to return it to the plaintiff. If equity considers as done that which ought to have been done, the equitable ownership of the recoverable asset should belong to the plaintiff.

Lord Millett's counter-argument, set out above, is that the defendant's duty to return the asset does not arise until the plaintiff elects to rectify or rescind the transaction. However, this problem could be handled by a trust which arises at the outset, but may be defeated by events which bring the right to rectification or rescission to an end, such as the plaintiff's election to affirm the transaction, the passage of time, or the acquisition of the asset by a bona fide purchaser. In a similar way, a person who obtained an asset in breach of fiduciary duty would hold it in constructive trust for the victim of that breach, but the trust would end if the victim ratified the transaction or the asset was acquired by a bona fide purchaser.

In any event, if a trust does not arise until the plaintiff elects to rectify or rescind the transaction, the plaintiff does have an equitable property right to the recoverable asset, which arises at the outset. At a minimum, it must be a right similar to that created by an option to purchase. If the exercise of the option leads to a specifically enforceable contract of sale, then the option is itself a property right. As Martland J. said, in Canadian Long Island Petroleums v. Irving Industries, "forthwith upon the granting of the option, the optionee upon the occurrence of certain events solely within his control can compel a conveyance of the property to him."101 The same is true of a plaintiff with a right to recover an asset through rectification or rescission. If he or she does not have the full equitable beneficial ownership of the asset before electing to exercise that right, there must exist a lesser equitable property right capable of binding third persons.

The lack of a property right to restitution pending rectification or rescission would have potentially undesirable consequences. This is because a plaintiff whose intention to benefit the defendant has been severely vitiated (for example, by a fundamental mistake or overwhelming influence) is less likely to come to her or his senses and elect to rectify or rescind the transaction than a plaintiff who is operating under a lesser degree of vitiation. In other words, as the vitiation increases and comes closer to producing an absence of intention to benefit the defendant, the plaintiff becomes more vulnerable to the risks of the defendant's insolvency and the intervention of the property rights of third persons.

For example, in Blacklocks, ${ }^{102}$ discussed above, the plaintiff mistakenly included more land in a conveyance to a purchaser than the parties intended. He continued to live on the portion of land he had mistakenly conveyed away and was blissfully unaware of his mistake until the purchaser sold the land to the defendant. Fortunately, 
the judge declared that the recoverable land was held in trust for the plaintiff from the moment legal title had passed by mistake to the purchaser. The defendant had notice of that trust because the plaintiff had remained in occupation of the land in question. A property right less than full beneficial ownership under a trust would suffice in this situation, but a mere personal right to rectify the transaction would not.

\section{Constructive or Resulting?}

As discussed above, all resulting trusts are created by unjust enrichment. Is the converse true? Are all the trusts created by unjust enrichment resulting? In other words, how should we classify the trusts which effect restitution of unjust enrichment in situations not involving an apparent gift or the failure of an express trust?

Whether resulting or constructive, it is clear that every trust which effects restitution of unjust enrichment is resulting in pattern. It carries the enrichment back to the person who experienced the corresponding deprivation. Therefore, if only some of these trusts are resulting, then the remainder are constructive trusts which are resulting in pattern.

The traditional classification of trusts, as express, constructive, or resulting, is based on the events which create them. Regardless of the label chosen to describe the trusts arising in response to a particular type of event, it is important that only one label is used. Otherwise, the system loses its utility. As discussed above, this is why the implied trust has fallen into disfavour. It duplicates the work being done by other categories of trust and blurs the distinctions between those categories. It only leads to confusion if we refer to some of the trusts created by consent as implied, especially if we also use that term to describe trusts created by operation of law. This is precisely the same problem we encounter if we allow the trusts created by unjust enrichment to be described as both resulting and constructive. Most constructive trusts arise in response to a breach of duty or to perfect intentions to benefit others. Using the same label to describe some, but not all, of the trusts which respond to unjust enrichment can only be a source of confusion.

Even if we could achieve a coherent classification of trusts based on trust-creating events, we would still face a greater problem caused by the isolation of trusts from other areas of law. Other legal rights and obligations are also classified according to the events which create them, but under the categories of consent, wrongs, unjust enrichment, and other events. The rational development of the law depends upon our ability to align trusts with other rights and obligations. We need to know, for example, whether a transfer was intended as a gift or a trust, whether the proper response to a breach of duty is an account of profits or a trust, and whether the proper response to an unjust enrichment is a debt or a trust. This goal is difficult, if not impossible, to achieve if the system used to classify trusts differs from the system used in most other areas of law. As Birks said:

The rights which arise under trusts (trust-rights) must be seen to arise from the events which create other kinds of rights. It is a question, first, of overcoming the barriers to communication, which means looking to see what is really going on beneath the labels, then of deciding which taxonomy is better.... 
The remaining question will be whether, if there is no third possibility, we are going to move over to saying that trust-rights arise from consent, wrongs, unjust enrichment, and miscellaneous other events; or, rather, to saying that all entitlements are express, implied, resulting, or constructive. ${ }^{103}$

The law of trusts will have to align itself with other areas of law. Although that goal may be a long way off, we can take a small step towards it by using the existing categories of trusts carefully and consistently and matching them, where possible, to the categories used in other areas. It is generally agreed that the trusts created by consent are express and the trusts created by wrongs are constructive. Can we say that the trusts created by unjust enrichment are resulting or do we call some resulting and the others constructive?

\section{Conclusion}

The connection between unjust enrichment and trusts continues to create problems for Canadians because of two controversial issues. We have not clearly identified the trusts which respond to unjust enrichment nor can we say when or why a trust is an appropriate response to unjust enrichment. Since Pettkus v. Becker, ${ }^{104}$ our attempts to resolve these issues have focused on the constructive trust, but without much success. There is good reason to believe that the answer lies in a proper understanding of the resulting trust. This idea has been gaining momentum in England, where Lord Millett said recently in "Restitution and Constructive Trusts" that "the development of a coherent doctrine of proprietary restitution for subtractive unjust enrichment is impossible unless it is based on the resulting trust as traditionally understood." 105 This needs to be considered carefully by Canadian lawyers and judges.

All resulting trusts arise by operation of law to effect restitution of unjust enrichment. This is a modest conclusion which could leave the resulting trust alone to operate in its traditional categories and do no more than lead to greater consistency and understanding of the law within those categories. However, that conclusion leads to a re-appraisal of the trusts responding to unjust enrichment in other situations. It is not clear whether they are also resulting or are constructive (but resulting in pattern). The more coherent solution is to label all trusts which effect restitution of unjust enrichment as resulting. Better still would be a plain label, such as "unjust enrichment trust."

It is not yet clear when a trust is an appropriate response to unjust enrichment. It is suggested above that a trust should arise when the unjust enrichment is an asset received by the defendant at the plaintiff's expense. The trust should continue to exist if that asset is used to purchase another asset, but perhaps only if the defendant is aware of the unjust enrichment at the time of the purchase. Otherwise, an equitable lien over the substitute asset might be a more appropriate response. If the unjust enrichment continues to survive only as value traceable into the improvement or maintenance of an asset, then any property right to restitution should be a lien and not a trust. If the

10s Supra note 93 at 410. 
unjust enrichment cannot be traced into a specific asset, then the plaintiff's right to restitution must be a personal claim for the value of that enrichment.

The proper development of this area of law has been impeded, not just by poor taxonomy and confusing terminology, but also by fears concerning the intrusion of trusts into commercial life. We are reluctant to say that a plaintiff should have a property right to restitution of unjust enrichment, because this means a trust and a trust means unwanted fiduciary duties, loss of limitation periods, and unexpected priorities against third persons. However, these are fears of the unknown which are often exaggerated.

There is a common assumption that all trustees are fiduciaries. It is clear that express trustees are fiduciaries, owing strict duties of loyalty to the beneficiaries they have undertaken to serve. However, it does not follow that all constructive and resulting trustees are also fiduciaries. ${ }^{106}$ This must depend on the trustee's knowledge of the trust and whether he or she has undertaken to look after the beneficiary's interests. As Hackney said:

[I]n what sense is it right to call the unknowing infant resulting trustee, into whose name property has been secretly and voluntarily transferred, a fiduciary? Such a person can have none of the duties or powers of the express trustee and ought to have only an obligation to restore the property on demand, if still in possession of it. Even reckless disregard of property one does not know one has (the infant, grown old, but still unknowing, negligently loses the property) should not produce liability. No more should innocent transfer on. ${ }^{101}$

It is also assumed by many that the existence of a trust will allow the plaintiff to circumvent the limitation periods normally applicable to claims for restitution of unjust enrichment. A closer look reveals that this is not true. There are many cases in which a claim to a trust arising by operation of law was subject to the same limitation period which applied to the event that gave rise to the trust. ${ }^{108}$

A trust of the unjust enrichment is a property right which can affect the rights of third persons, but that is the point of a property right. However, as an equitable right it is subject to the defence of bona fide purchase. That defence has worked for centuries as a method of resolving competing claims to the same asset. There is no reason to suspect that it cannot fulfil the same function for property rights created by unjust enrichment. A bona fide purchaser will take the asset free of the plaintiff's right to restitution, but there is no reason why a donee or a purchaser with notice of the unjust enrichment should have that same freedom. 
In addition, a property right created by unjust enrichment should, like all rights to restitution of unjust enrichment, be subject to the defence of change of position. ${ }^{109}$ Where the property right is a lien, it will decrease in value along with the personal obligation which is secured by that lien. Where the property right is a trust of all or a portion of the beneficial ownership of an asset, the court will need to make the assertion of that right conditional upon reimbursement of the trustee for the value of her or his change of position.

In short, there is no reason to fear that the wider use of the resulting trust to effect restitution of unjust enrichment will cause any greater difficulties than personal rights to restitution. On the contrary, there is much to commend it. If a defendant is unjustly enriched because he or she has received an asset at the plaintiff's expense, there is no reason why the defendant's creditors should be entitled to that asset. The creation of a trust in response to that unjust enrichment merely compels the defendant to fulfil the duty to return the asset which he or she was not intended to have. The creditors are left no worse than they would have been if the unjust enrichment had not occurred. 